\title{
Direito e Regulação na Internet: desafios jurídicos e oportunidades para o crescimento econômico*
}

Internet Law and Regulation: Legal Challenges and Opportunities for Economic Growth

Brad Smith $^{* *}$

Evento: Seminário Direito e Regulação na Internet

Realização: Microsoft Corporation

Palestra proferida em 3 de outubro de 2011

Local: Faculdade de Direito da Universidade de Brasília

Obrigado a todos por terem vindo nesta manhã. É um prazer para mim estar aqui, em Brasília, com todos vocês. O que eu gostaria de fazer esta manhã é, em primeiro lugar, tratar de alguns temas para, em seguida, abrir a discussão para dialogarmos sobre o que for do interesse de todos e responder a quaisquer perguntas que tenham. O que eu pensei em tratar aqui é sobre para onde a internet está indo, para onde a tecnologia está indo, como as coisas estão mudando e como nós e uma empresa como a Microsoft pensamos que as coisas mudarão nos próximos anos. Em um segundo momento, pensei em conversar um pouco sobre o que tais transformações significam para o Brasil, em especial, as oportunidades econômicas, os desafios econômicos que terão que ser enfrentados para que o Brasil, assim como outros países, é claro, possam aproveitar ao máximo esta mudança tecnológica. Finalmente, em um terceiro momento, tratarei do direito, da política e da regulação, bem como das novas questões que estão aparecendo ao redor do mundo e no Brasil.

Mas deixem-me iniciar primeiro com a tecnologia. É realmente interessante perceber como a tecnologia está mudando a forma com a qual as pessoas interagem com computadores. Se pensarem a respeito disso, na

\footnotetext{
*Versão escrita e tradução para a língua portuguesa de Daniel Costa Rebello, autorizada pelo autor.

${ }^{* *}$ Vice-Presidente mundial da Microsoft Corporation e seu primeiro responsável mundial pela área de assuntos jurídicos e corporativos.
} 
maior parte dos últimos vinte anos, as pessoas imaginaram o computador apenas como um PC - o computador pessoal. Ele pode estar na sua mesa, ele pode ser o seu laptop, podemos andar com ele e de fato vimos essa tendência se alastrar pelo ao redor do mundo. Quando Bill Gates fundou a Microsoft nos anos 70, ele de fato o fez com uma visão de que o computador pessoal iria se tornar um aparelho onipresente ao redor do mundo. De fato, a missão originalmente definida para a Microsoft era a de alcançar "um computador em cada mesa e em cada lar". De fato, em várias partes do mundo e em vários países, essa visão torna-se cada vez mais verdadeira. Tanto é assim que nós basicamente a tomamos como um dado. Isso tem mudado de forma tão rápida que é fácil esquecer como essa visão era radical há apenas trinta anos atrás. De fato, em 1977, o CEO da segunda maior empresa de computação no mundo disse que não havia absolutamente razão alguma para que alguém jamais quisesse possuir um computador em sua casa. É claro, essa empresa não mais existe. Isso provavelmente ocorreu porque ela lutou contra a maré e o seu tempo. Mas isso apenas mostra que aquilo que tomamos como premissa ou consideramos serem possíveis ou impossíveis em um momento, podem mudar rapidamente uma década ou duas depois.

Estamos em uma nova década, um novo século. O que realmente estamos vendo é o computador, que pensávamos ser somente o PC, mas que hoje se apresenta em três ou quatro formatos de telas perante todos nós. Durante a última década, certos dispositivos se transformaram em computadores: os smartphones são, de fato, pequenos aparelhos de computação. Ou seja, não temos somente um computador em nossas mesas, mas um computador em nossos bolsos e, em muitas partes do mundo, é claro, os smartphones estão sendo adotados somente agora. Não é, entretanto, dífícil de se imaginar que, até o final desta década, a maior parte dos telefones serão smartphones. Por volta do ano 2020, a maior parte dos telefones serão computadores.

Assim, em um extremo, temos as telas dos smartphones; no lado oposto do espectro, temos as grandes telas planas tornando-se cada vez mais populares. Quero dizer com isso que, literalmente, nos últimos dez anos, nós temos visto as telas de televisão tornarem-se ao mesmo tempo maiores e mais finas. Ao final desta década - digamos, no ano 2020 - acredito que veremos a maior parte das televisões tornarem-se televisões conectadas a 
computadores também. Elas podem até mesmo estar conectadas à internet. Haverá uma variedade de formas pelas quais as pessoas provavelmente as controlarão. Nós já investimos pesadamente nisso com o Xbox. Vocês podem antecipar o fato de que as pessoas usarão um controle ou outro pequeno aparelho como um telefone, ou um tablet ou gestos caso elas utilizem a tecnologia que nós estamos construindo no Xbox para controlar suas TVs.

Pode-se ver como o mundo passará, de forma efetiva, da condição de se possuir uma única tela ligada ao computador para três telas que estão conectadas ao computador: a TV, o PC ou laptop, e o telefone.

Outro aspecto relevante diz respeito a um assunto sobre o qual as pessoas estão apenas começando a se preocupar: se de fato haverá uma quarta tela que as pessoas usarão. Esse pode ser o fator tablet, o iPad de hoje e isso é bastante possível. Ou, por outro lado, nós podemos ver ao longo do tempo uma convergência entre, digamos, o laptop e a forma de tablet, porque é possível que as pessoas não desejem realmente uma quarta tela em suas vidas; três podem ser o suficientes. E se for o caso, nós veremos isso acontecer também.

De certa forma, ao invés de um computador em cada mesa, temos, na verdade, atualmente três ou quatro telas na vida de várias pessoas. E isso será mais e mais corriqueiro nos próximos dez ou vinte anos. Parte do que torna isso possível é a quantidade significativa de avanços tecnológicos incidentes sobre o que as pessoas entendem por aparelhos [devices]. Os aparelhos estão se tornando menores, mais leves, mais poderosos. A vida útil da bateria tem melhorado e as pessoas estão cada vez mais interagindo com computadores ao tocar em suas telas ou mediante gestos.

Mas há ainda outro aspecto que efetivamente tem sido alterado em termos de tecnologia: é o que nós chamamos de nuvem. A computação em nuvem tornou-se um termo usado diariamente no setor, mas ele quer significar, de fato, a pessoas rodando softwares que estão em um datacenter, ou seja, na nuvem, como as pessoas gostam de chamá-la. Sob certo ponto de vista, a nuvem já existe há bastante tempo, mas ela está mudando muito rapidamente.

Qualquer pessoa que usou o Hotmail, na última década, o Gmail, ou o Yahoo! Mail, ou qualquer outro serviço de correspondência eletrônica [email], na verdade, utilizou uma versão de computação em nuvem por um 
longo tempo. A correspondência eletrônica [email] é armazenada na nuvem. Os dados estão na nuvem. O software está na nuvem. Eles podem ser replicados em cada aparelho pessoal, mas desnecessariamente. Pode-se, simplesmente, acessar um navegador [browser] para se fazer tudo que se queira com sua correspondência eletrônica. Outro exemplo de uso de serviço em nuvem está na utilização de mecanismos de busca na internet, como o Google ou o Bing, ou outro serviço qualquer. Se pensarem em como a busca funciona, o que ocorre é o seguinte: vocês digitam o que desejam em seu próprio aparelho, mas o programa que realiza o trabalho está em um datacenter e toda a informação está em datacenters, em inúmeros computadores e servidores dentro de um datacenter.

Passa despercebido para nós o fato de que nós digitamos o que nós desejamos em nossos próprios computadores e, então, o datacenter realiza todo o trabalho. Em um piscar de olhos, os resultados de nosso pedido de busca são devolvidos para nós em nossos próprios computadores. Esse é um outro bom exemplo de um serviço em nuvem.

O serviço em nuvem, entretanto, já está sendo prestado há dez anos ou mais, e vocês podem se perguntar o que está mudando. A verdade é que muito está mudando, porque serviços de nuvem estão avançando rapidamente para um ponto em que quase todo software que anteriormente estava em um servidor está agora se mudando para a nuvem; para um datacenter. Existem, assim, dois grandes tipos de serviços emergindo na nuvem.

Um deles é o serviço para os consumidores. Hoje em dia, estamos presenciando não apenas serviços de busca na internet e correspondência eletrônica [email]. Qualquer pessoa que utilizou o Skype, na verdade utilizou uma outra versão de serviço em nuvem. Esse serviço é obviamente um serviço que conecta pessoas ao redor do mundo, ou dentro de um campus universitário, e que faz uso da nuvem.

Outro tipo de serviços dizem respeito aos serviços para empresas. Podese pensar em algo como o Microsoft Office. No Brasil, no próximo mês, nós lançaremos uma versão desse produto baseada em nuvem denominada Office 365, pois estará disponível todos os dias do ano. Ele inclui não apenas os aplicativos que vocês conhecem, como o Powerpoint, o Word e o Excel. Ele também inclui serviços de hospedagem de correspondências eletrônicas, como o Outlook e o Exchange. Ele inclui também o SharePoint, 
que é um serviço de servidor que nós criamos e que permitem que pessoas compartilhem documentos. Ele inclui uma versão corporativa de um software de colaboração chamado Microsoft Lync, que oferece a possibilidade de uso de vídeo, mas também a possibilidade de pessoas trabalharem em conjunto e compartilharem informação a compartilharem documentos e assim por diante.

Assim, vemos esses dois conjuntos de serviços emergindo na nuvem. Um para consumidores; e outro para empresas.

Nós vislumbramos também uma nova plataforma que está emergindo, na qual as pessoas podem criar seus aplicativos. A Microsoft teve uma versão de rede do Windows por muitos anos, chamada Windows Server. Nós criamos uma nova versão do Windows, denominada Windows Leisure, que é executado em um datacenter, permanece na nuvem, e permite que pessoas escrevam aplicativos e os armazenem na nuvem, em um datacenter.

Vocês podem se perguntar o que há nisso tudo que os torna atraentes, pois o que os torna atraentes é o que está efetivamente mudando a própria natureza da computação.

O primeiro aspecto que os torna atrativo diz com o fato de que a computação em nuvem torna muito mais barato ofertar serviços. Por quê? Porque há enormes economias de escala ao se colocarem todos esses computadores em um datacenter. Se pensarem em serviços de computação hoje, sabe-se que universidades, governos e empresas podem contar com servidores próprios. Isso criou ao redor do mundo vários espaços dedicados a servidores. Para quem já viu uma instalação de servidores [server room], sabe que nela existem estantes com servidores em um ambiente com intenso controle de temperatura para garantia de preservação da temperatura ideal. Assim, todos têm que ter suas próprias instalações de servidores. Com a computação de nuvem, não é mais preciso que se construa uma instalação de servidores. Ao invés disso, uma empresa como Microsoft, ou Amazon, ou Google ou IBM criam instalações para servidores e é bem menos caro para uma empresa fazer isso em grande escala, pois em primeiro lugar isso significa que nós podemos comprar os servidores, mediante desconto em razão do volume quando nós compramos em grande escala. Em segundo lugar, nós podemos criar uma única instalação que é dedicada em larga escala para ter esses computadores. Mas o terceiro aspecto que realmente direciona as economias de escala está no custo com pessoal. Se pensarem no 
que é preciso para se ter uma instalação de servidores, uma das necessidades básicas está em termos acesso a um ser humano a quem possamos acessar sempre que um dos servidores precisar ser atualizado, ou precisar ser reconfigurado para uma nova versão de software, ou quando ocorre algum problema e o servidor precisa ser reiniciado. Com isso, de fato, o custo de pessoal associado às instalações de servidores tende a ser um dos mais onerosos. Ter um datacenter em empresas que se especializam nesses serviços permite que um número menor de pessoas, trabalhando 24 horas por dia, 7 dias por semana, mantenham todos os servidores do data room. Como consequência disso, os custos de se manter um servidor começa a cair de forma dramática.

Há, entretanto, ainda mais benefícios do que apenas as economias de escala. Ganha-se uma enorme agilidade porque se vocês estiverem em um negócio hoje, se vocês oferecem um serviço, precisarão de um servidor, um número de servidores em suas instalações de servidores ao menos igual ao necessário quando se atinge a capacidade de pico. É necessário, portanto, preocupar-se com o dia mais ocupado do ano. Se vocês forem um varejista, esse dia será na semana anterior ao Natal. Se você fizerem parte de uma atividade que tenha relação com o fornecimento de serviços para eventos de esporte, pode ser o dia do ano antes ou o dia do ano de seu maior evento esportivo. Dessa forma, vocês precisarão adquirir todos esses servidores, de modo que possam manter a capacidade necessária para o seu dia de maior tráfego. No entanto, em todos os outros dias do ano, vocês basicamente terão vários servidores com capacidade ociosa. Com a computação em rede, vocês pagam na medida do que precisam. A qualquer momento e de forma automática, pode-se adquirir maior capacidade nos servidores de acordo o que for necessário. Quando a capacidade contratada não for mais necessária, pode-se reduzir rapidamente sua prestação, diminuindo-se o preço do serviço.

O benefício do uso da computação em nuvem não se resume, obviamente, a sua agilidade, mas também decorre do quesito velocidade. Pode-se alterar para mais ou menos, rapidamente, a velocidade contratada. Se vocês precisarem atualizar o seu software, poderão programar o "atualize você mesmo" e depois atualizar nos servidores do datacenter para que essa atualização se torne disponível para todos os seus usuários de forma instantânea.

Revista de Direito, Estado e Telecomunicações, v. 4, n. 1, p. 197-236 (2012)

DOI: https://doi.org/10.26512/lstr.v4i1.21579 
Existe um caso muito interessante que ilustra como a computação em nuvem funciona e por que ela é tão interessante. Sei que um grande evento aqui no Brasil, recentemente, foi o Rock in Rio. Como todos sabemos, o Rock in Rio é muito popular e tem vendido os seus ingressos online. Se qualquer um de vocês ou seus amigos compraram ingressos online para o evento, utilizaram, na verdade, um serviço que roda na nuvem, em um datacenter da Microsoft, que tem o Windows como sua plataforma. Ele é oferecido por uma empresa chamada Zecks. Agora, o que é realmente interessante sobre essa empresa é que ela foi fundada ano passado e ela possui apenas três empregados, mas esses três empregados foram capazes de criar um serviço para vender todos os ingressos do Rock in Rio online. Em um espaço de tempo de quarenta horas, eles venderam 525.000 ingressos. Antes da computação em nuvem, seria impossível para três pessoas criarem uma empresa e pensarem em entregar de forma online 525.000 ingressos em quarenta horas, mas utilizando-se do Windows, eles foram capazes de criar o software e projetar o serviço e depois apenas realizar o upload dele para o datacenter da Microsoft. Eles não tiveram de adquirir quaisquer servidores de computador. Quando eles viram o repentino crescimento de sua necessidade de utilização, ao invés de terem alguém correndo o mais rápido possível e conectando outros servidores, eles simplesmente obtiveram a capacidade extra de que precisavam no datacenter da Microsoft. Quando finalmente todos os ingressos foram vendidos, eles puderam simplesmente retornar para a menor quantidade de que precisavam sem a necessidade de continuar pagando por muito mais.

Esse exemplo demonstra como computação em nuvem pode simplesmente transformar a forma segundo a qual o setor de tecnologia da informação funciona e a forma como pequenas empresas em particular podem começar seus negócios e imediatamente utilizar esse tipo de serviço para fornecer um novo benefício às pessoas. Essa a dimensão da computação em nuvem expressa para onde o mundo está caminhando. Ela ilustra o fato de que dentro de poucos anos, o que nós iremos ver cada vez mais são pessoas com múltiplos aparelhos - do telefone ao laptop, à TV todas confiando na nuvem para fornecer conteúdo e serviços.

Se é para aí que a tecnologia está caminhando, acredito que valha à pena pensarmos um pouco sobre a segunda parte desta exposição, ou seja, sobre o que isso significa para o Brasil. Eu na verdade acredito que isso significa 
muito para o Brasil em parte porque o Brasil está em um momento tão empolgante em relação ao setor de tecnologia da informação. O Brasil avançou a passos largos em termos de sua importância para o mundo no que tange à tecnologia da informação. Até o ano que vem, estima-se que o Brasil será o terceiro maior mercado mundial em venda de computadores pessoais. Ele ultrapassará o Japão. Haverá apenas dois países na frente do Brasil: a China e os Estados Unidos. Assim, o Brasil será o terceiro país do mundo para computadores pessoais. O Brasil já é o quinto colocado no mundo em utilização da internet. Ele já é o sexto colocado no mundo em termos de utilização de telefone celular. Com o enfoque em investimentos em tecnologia de banda larga - uma área na qual o Brasil é atualmente o número dez do mundo - pode-se ver facilmente como com uma conexão melhor de banda larga haverá ainda maior utilização da internet, maior utilização de telefones celulares e, ao final, de smartphones, todos somados à utilização de computadores pessoais.

O Brasil viu, e continuará a ver, um crescimento muito forte em seu produto interno bruto a taxas de 7,5\% no ano passado e provavelmente $4,5 \%$ neste ano. O Brasil possui uma baixa taxa de desemprego. Eu posso dizer a vocês que eu estive em muitos países ao redor do mundo que adorariam ter a taxa de desemprego que vocês possuem aqui no Brasil, de apenas 6\%. Parte da razão que tem levado a uma baixa taxa de desemprego é o grande crescimento de oferta de emprego no setor de tecnologia da informação. Hoje, cerca de 1,3 milhões de pessoas trabalham no setor de tecnologia da informação no Brasil. Projeta-se que esse número cresça para 1,6 milhões de pessoas até o ano de 2013. Acredito ser razoável progetar-se, em um país com cerca de 195 milhões de habitantes, cerca de 1,6 milhões de pessoas trabalhando no setor de tecnologia da informação nos próximos dois anos. Em outras palavras, cerca de uma em cada 100 pessoas vivendo no Brasil, consideradas todas as idades, trabalharão no setor de tecnologia da informação.

Essa é uma das razões pelas quais uma empresa como a Microsoft tem se esforçado tanto em investir no Brasil. Esse investimento ocorre de várias formas diferentes. Cada vez mais há produtos que nós estamos desenvolvendo no Brasil. O produto SharePoint, que foi mencionado anteriormente, é em parte desenvolvido no Brasil. Há outro produto que foi criado para pequenos negócios denominado Dynamics, que foi criado 
parcialmente no Brasil. Nós possuímos centros de desenvolvimento que empregam desenvolvedores em São Paulo e no Rio de Janeiro. Isso também ajuda a explicar o porquê de, na semana passada, nós termos anunciado que iremos fabricar o Xbox aqui no Brasil, em Manaus. Ou seja, nós temos produtos que estão sendo inventados aqui no Brasil; nós temos produtos que estão sendo fabricados aqui no Brasil.

Para uma empresa como a Microsoft, isso significa não apenas o nosso crescimento, mas a proposta de auxiliarmos o crescimento do ecossistema de nossos parceiros. Uma das características interessantes da Microsoft é que nós basicamente vivemos ou morremos, se assim desejarem, em um modelo de parceria. Com isso eu quero dizer que nós temos muito mais pessoas que trabalham para nós como parceiros do que trabalham diretamente para a Microsoft. Nós temos pouco mais de 600 empregados aqui no Brasil, mas nós temos mais de 18.000 parceiros no Brasil. De fato, esses 18.000 parceiros empregam cerca de 230.000 pessoas. Com isso, nós somos muito dependentes não apenas de nossa capacidade de fazer o que fazemos dentro da Microsoft, mas, em várias aspectos, nós somos muito dependentes da vitalidade de nossos parceiros. Na verdade, para cada real que nós geramos como uma empresa aqui no Brasil, nossos parceiros geram vinte vezes esse valor.

Assim, quando nós pensamos sobre o que será necessário para continuar crescendo aqui no Brasil, muito disso está em auxiliar o crescimento de nossos parceiros. Isso significa, em realidade, ajudar nossos parceiros e ajudar o país a desenvolver as habilidades adicionais da população para tirar vantagem das oportunidades de crescimento contínuo.

Nós estamos efetivamente interessados no desenvolvimento de habilidades primeiro para nossos parceiros de negócios e depois para a juventude de forma geral. A forma como nos concentramos no desenvolvimento de habilidades para nossos parceiros ocorre por intermédio da criação e gerenciamento do que nós chamamos de centros de inovação. A Microsoft tem 25 centros de inovação pelo Brasil. Esse número equivale a um quarto de todos os nossos centros de inovação no mundo. Há um aqui em Brasília e há outros 24 no Brasil afora.

O enfoque guia de nossos centros de inovação é o de ajudar nossos parceiros a continuar aumentando suas bases de habilidades. Em particular, nós nos concentramos em ajudar novas empresas a começarem suas 
atividades. Estima-se que, nos próximos três anos, 2.300 novas empresas serão criadas aqui no Brasil no setor de tecnologia da informação. Isso surgirá de novos empreendedores, inclusive dos que hoje cursam a Universidade. Assim, trabalhamos por meio de nossos centros de inovação ajudando a iniciar novos negócios.

Nós temos um programa que nós chamamos de BizSpark. Este ano o BizSpark está trabalhando para que 1.300 empresas sejam criadas no Brasil. Nós damos a elas acesso gratuito à nossa tecnologia e ao nosso software e nós fornecemos vários programas de treinamento para ajudá-las a serem criadas e começarem suas operações.

Em outra frente, os centros de inovação auxiliam aos negócios a se conectarem aos estudantes que desejam seguir uma carreira nesse ramo. Nós temos um programa denominado "Students to Business". Este ano, aqui no Brasil, esse programa está trabalhando com 1.700 estudantes para ajudá-los a serem treinadose para depois os ajudarmos a travarem contato com os negócios que temos auxiliado, para que os estudantes possam ser contratados e terem empregos no setor.

Descreveu-se assim uma grande parte de como nós ajudamos o ecossistema a crescer e a aproveitar essas oportunidades. De fato, aquela história que mencionei sobre a Zeks - a empresa de venda de ingresso online -, foi uma empresa que criada pelo nosso trabalho por intermédio dos centros de inovação e com o programa BizSpark.

Nós também reconhecemos como necessário implementares atividades que vão além do auxílio à criação de empresas. Trata-se de um tema relevante aqui no Brasil e em vários outros países: a disponibilização de maiores oportunidades para a juventude e uma melhor educação. Há cerca de 10 anos, as pessoas em nossa indústria começaram a falar sobre o que elas viam como a divisão digital. Eles se referiam ao fato de que os computadores eram acessíveis para uma parte da população, mas inacessíveis para a outra parte. Nós estamos nos esforçando em diminuir a divisão digital, mas cada vez mais temos nos concentrado no que nós chamamos de divisão de oportunidade, quando nos referimos ao fato de que há uma parcela da população que está indo bem em termos de educação, enquanto uma outra parcela da população, aqui no Brasil e em todos os outros países, não se tem beneficiado das oportunidades da mesma forma. Eles não estão indo à universidade. Em muitos casos eles não estão 
completando sequer o ensino médio ou o ensino fundamental. E se olharem para o que a população precisará para ser bem-sucedida no futuro, é evidente que a obtenção de uma melhor educação, incluindo a educação tecnológica, é uma peça realmente importante do quebra-cabeças. Por isso, fizemos disseo nosso enfoque mais amplo como empresa. É a causa que nós adotamos, se preferirem, no Brasil e em vários outros lugares.

Estamos fazendo várias coisas para enfrentar essa questão. Em primeiro lugar, estamos tentando ajudar as escolas a obter melhor acesso à tecnologia nas próprias escolas. Temos um programa chamado "Partners in Learning". Esse programa treina professores e alunos no uso da tecnologia do computador e ele fornece às escolas um acesso de baixo custo à própria tecnologia. Aqui no Brasil, este ano, nós treinaremos 33 mil professores, por todo o país e nós forneceremos a eles o curriculum e as habilidades para que eles possam fazer melhor uso dos computadores nas escolas. Esse é um programa que está acontecendo desde 2003 e nós agora alcançamos a marca de quase meio milhão de professores em todo o Brasil.

Nós também reconhecemos que um ótimo lugar para encontrar alunos é, não apenas nas escolas, mas em outros lugares que os estudantes frequentam. Então nós também trabalhamos com centros de tecnologia comunitária. Por meio da combinação de escolas com esses centros tecnológicos, nós alcançaremos cerca de 2,9 milhões de pessoas, este ano, no Brasil. Isso nos permitirá expandir as oportunidades para a juventude em todo o país.

Nós também temos um programa projetado para estudantes que possuem um interesse específico em tecnologia e que realmente desejam se concentrar no campo tecnológico. Ele é chamado de "Magic Cup". Esse programa é uma competição que ocorre no Brasil e em países por todo o mundo, que fornece às pessoas a oportunidade de competir criando novos aplicativos de software. Nela, os competidores têm a oportunidade de vencer no nível nacional e, ao final, a oportunidade de vencer ao nível mundial.

Consequentemente, por intermédio desses tipos de programas, nós estamos realmente tentando desenvolver melhores oportunidades para a juventude e para a educação. Se nós conseguirmos fazer isso, juntamente com nosso trabalho por novos negócios, nós poderemos ajudar a criar as habilidades básicas que serão necessárias para a indústria crescer e para a 
economia crescer aqui no Brasil, e, esperamos, reduzir a divisão de oportunidade.

Agora eu gostaria de voltar a atenção de vocês para o terceiro tópico que, para alguns de vocês, é talvez o tópico de maior interesse. Trata-se da questão: o que isso tudo significa para o direito; o que isso significa para as políticas públicas; o que isso significa para a regulação, na medida em que as coisas avançam. Penso que há três aspectos que são especialmente importantes para a política, para a regulação e para o direito.

O primeiro tem relação com a promoção para adoção de banda larga. Vocês me ouviram falar antes: o Brasil é o número três em termos de computadores pessoais no mundo, mas apenas o número dez em adoção de banda larga. Se existe um fator que ajudará a direcionar todos esses serviços ao Brasil nos próximos vários anos, ele está no tipo de iniciativa que o país está perseguindo no Programa Nacional de Banda Larga. Se conseguirmos alcançar uma banda larga disponível de forma mais abrangente ao lado do acesso a baixo custo, isso trará serviços para mais casas, tornará tais serviços disponíveis em smartphones e fornecerá às pessoas a oportunidade de abrir novos negócios em torno desses serviços.

Essa é uma área apropriada à inovação e política governamental. Nós estamos realmente animados com uma nova tecnologia chamada "super Wi$F i$ ". Ela consiste em uma forma de conexão banda larga sem fio, mas que, com o apoio da política governamental correta, acreditamos que se tornará disponível de forma universal e poderá ser especialmente importante na conexão de áreas rurais do Brasil de forma mais célere. Todos nós nos acostumamos a redes de Wi-Fi. Elas hoje estão geralmente disponíveis apenas em pequenas localidades. Nós todos sabemos que os sinais de Wi-Fi não alcançam grandes distâncias. $\mathrm{Na}$ verdade, eles frequentemente não atravessam bem as paredes. No entanto, utilizando-se o que é chamado de padrão 802.11, o Wi-Fi tornou-se uma plataforma bem-sucedida. O que é interessante sobre o super Wi-Fi, conforme a nomenclatura que tende a ser adotada, é que ele é uma espécie de Wi-Fi com esteróides. Ele é muito mais poderoso. Ele se utiliza da faixa de $500 \mathrm{MHz}$ do espectro de radiofrequência. Essa é uma parte do espectro que hoje é utilizada para sinais de televisão terrestre. Se pensarmos a respeito do que tomamos como um dado por décadas no que tange às televisões é que, em primeiro lugar, os sinais de televisão viajam por uma longa distância. Eles são muito mais Revista de Direito, Estado e Telecomunicações, v. 4, n. 1, p. 197-236 (2012) 
poderosos porque o seu comprimento de onda viaja muito mais distante. É muito diferente do Wi-Fi. Em segundo lugar, esses tipos de sinais atravessam com facilidade as paredes. Assim, ao contrário de se conectar um laptop a um sinal de $\mathrm{Wi}-\mathrm{Fi}$, é muito mais fácil simplesmente ligar a televisão com uma antena tradicional que ela funcionará.

O que o super Wi-Fi faz é utilizar a capacidade inutilizada dessa parte do espectro: a faixa de 500-800 MHz. Por isso, o super Wi-Fi é frequentemente chamado de espaço em branco [whitespace]. O espaço inutilizado na faixa de televisão terrestre. $\mathrm{O}$ que os reguladores estão começando a pensar é em abrir essa faixa para que ela possa ser utilizada por empresas que forneçam serviços de banda larga.

Nós estamos experimentando um serviço na Universidade de Cambridge, que está disponibilizando conexão super Wi-Fi, para pessoas daquela área. Na semana passada, estive em reuniões das Nações Unidas em Nairóbi, no Quênia. Uma das coisas que o Ministério da Informação e Comunicações do Quênia fez foi tornar possível para nós montarmos uma rede super Wi-Fi e demonstrar como isso funciona em Nairóbi. Tudo o que nós tivemos que fazer foi basicamente montar uma antena muito simples em uma caixa e isso tornou a conexão super Wi-Fi disponível em até um quilômetro de distância. Pude sentar com um Xbox e com uma televisão de alta definição e acessar o sinal que estava vindo sem fio de um quilômetro de distância e eu fui capaz de rodar vídeos de alta definição pelo Xbox nessa tela, como também me conectar conectar com outras pessoas jogando um jogo, utilizando vídeos em alta definição.

Vocês podem imaginar o quanto a conexão com um sinal emitido a um quilômetro de distância, a custos mínimos, pode transformar a conexão de banda larga. Trata-se do tipo de decisão que pode alterar a forma como as pessoas utilizarão a tecnologia de computação na próxima década. Esse é um bom exemplo da necessidade das agências reguladoras repensarem o uso do espectro; em como elas podem tornar mais faixas de radiofrequências disponíveis, em parte, como espectro licenciado para 3G, 4G e LTE, mas também espectro não licenciado.

Quando se utiliza de uma rede Wi-Fi hoje, o que se está utilizando é de espectro não licenciado, ao passo que quando nos conectamos via telefone celular, estamos usando espectro licenciado. Nós entendemos que é muito importante para o regulador tornar ambos disponíveis - mais espectro 
licenciado e mais espectro não licenciado. De certo modo, o espectro não licenciado é um motor mais potente de inovação, pois quando ele é criado, não se sabe como as pessoas o utilizarão. Ao se disponibilizar espectro não licenciado, há um real incentivo à inovação e isso acelera a adoção de tecnologias em novas formas que podem ser muito poderosas. Assim, essa é a primeira questão sob uma perspectiva regulatória - eu acredito que é, na verdade, uma questão de telecomunicações - pertinente à disponibilização de espectro; a garantia de que as pessoas possam utilizá-lo de uma forma livre e acessível.

Como vocês pode ter ouvido falar, a Microsoft celebrou um acordo em maio para adquirir o Skype. Quantos de vocês já utilizaram o Skype? Na maior parte dos lugares, a maior parte dos estudantes utilizou o Skype. Eu tenho dois filhos e eles já o utilizaram também. O meu filho está na universidade: se eu quero contactá-lo, é melhor que eu utilize o Skype. Nós esperamos que durante as próximas duas semanas já tenhamos a aprovação regulatória final para adquirir o Skype, quando ele será parte da Microsoft. A primeira coisa que eu posso dizer a vocês é que tudo que vocês gostam nele, hoje, continuará da mesma forma. Ele continuará de graça, ele terá as mesmas ferramentas que vocês estão acostumados a usar.

Mas ao comprar o Skype, nós seremos capazes de fazer um conjunto de outras coisas. Nós seremos capazes de integrar o Skype em novas formas, de modo que se possa utilizar o Skype no Xbox. Será possível utilizar o Skype em todos os telefones disponíveis e nós poderemos conectar o Skype com serviços adicionais, de modo que ele se tornará mais e mais poderoso ao longo do tempo. Como vocês sabem, o Skype basicamente fornece o que é chamado de voz sobre IP: voz sobre o protocolo de internet. Uma das coisas que nós esperamos que os reguladores continuem fazendo no Brasil e ao redor do mundo é permitir que consumidores façam uso completo de VoIP, ou da tecnologia de voz sobre o protocolo de internet, para que ele possa continuar a ser mais e mais utilizado e nós possamos continuar inovando. Essa é uma outra peça muito importante na perspectiva das telecomunicações.

O segundo conjunto de assuntos que acredito seja ainda mais importante em um contexto de computação em nuvem está relacionado à proteção à propriedade intelectual. Nós, da Microsoft, vemos um conjunto de novos 
assuntos emergindo para o software e para sua proteção sob as leis de propriedade intelectual.

Um dos aspectos interessantes a respeito do software é que ele é, na verdade, governado por uma variedade de diferentes campos de propriedade intelectual de forma simultânea. Em primeiro lugar, nós temos que pensar sobre software sendo protegido por copyright. O copyright refere-se basicamente ao ramo do direito que protege o software contra a pirataria generalizada, que é um problema sério no mundo e, no Brasil, alcança uma taxa percentual de 54\%, que foi consideravelmente reduzida nos últimos cinco anos. Mas o que ela significa é que toda vez que uma pessoa está pagando por um programa, há mais de uma pessoa copiando-o de forma ilegal. Por isso, nós achamos que serão necessários novos passos para proteger o copyright. Há algumas novas iniciativas em desenvolvimento, no nível estadual, nos Estados Unidos, que procuram promover maior respeito à proteção de copyright para software.

A segunda área do direito que é importante para o software é o direito de registro de marcas. Ele desempenha um enorme papel na proteção de software contra a falsificação. Produtos como o Windows, o Office, o Adobe Reader e o AutoCADE e vários outros produtos são falsificados de forma corriqueira. Há uma empresa chamada Rosetta Stone, que faz softwares de tradução de idiomas, que é muito popular ao redor do mundo para pessoas que querem aprender um novo idioma. O Rosetta Stone é falsificado de forma muito abrangente em todo o mundo; da mesma forma que o Microsoft Windows e o Office o são. A internet também tem sido utilizada para transportar produtos falsificados ao fazer propaganda deles, aumentando a carga de pedidos. Com isso, o direito de registro de marcas continua sendo muito importante para auxiliar na proteção contra falsificações.

A terceira área do direito que é muito importante é o direito de patentes. Como vocês devem saber, há várias discussões sobre patentes hoje no contexto de telefonia celular. Se vocês estiverem interessados, eu ficarei mais que satisfeito em falar sobre alguns deles. Nós, da Microsoft, enxergamos que a lei de patentes continua sendo um campo, em minha opinião, de inovação no setor de tecnologia da informação. É interessante pontuar que, se quiserem patentear uma inovação hoje, independentemente do país em vivem, o primeiro país para o qual provavelmente irão são os 
Estados Unidos. Os Estados Unidos tornaram-se o país da vez em termos de patenteamento de novas invenções. Mas há outros países que estão se aproximando rapidamente dos Estados Unidos. O sistema de patentes na China está experimentando um crescimento explosivo, assim como o sistema de patentes na Coréia e o sistema de patentes no Japão.

A área de patentes é, na verdade, uma área na qual o Brasil continua muito atrasado. De fato, ela quase que se sobressai, de forma singular, como sendo uma área na qual o Brasil - eu diria - continua a investir menos que o necessário. Costuma-se medir ao redor do mundo o número de pedidos domésticos de patentes por PIB. Se olharem para o mundo de hoje, a China é hoje o número quatro no mundo em termos de pedidos domésticos de patentes por PIB. A Rússia tornou-se o número nove. Quando pensamos nesses países, nós normalmente pensamos que o Brasil estará mais ou menos na mesma colocação, mas, ao passo que a China é o número quatro e a Rússia é o número nove, o Brasil é o número quarenta e três. Ou seja, as pessoas que moram aqui no Brasil e que estão inventando novos produtos, não os estão patenteando aqui no Brasil da forma como ocorre na China ou na Rússia. Acredito que este seja um tópico realmente interessante, francamente, para se pesquisar, vale dizer, o motivo desse estado de coisas.

$\mathrm{Na}$ minha perspectiva, eu diria que parte da resposta é a seguinte: o sistema de patentes no Brasil é incrivelmente lento. Leva muito mais tempo, por exemplo, em nossa indústria, para ter um pedido de patente aprovado no Brasil, do que no Japão, nos Estados Unidos, na Coréia, na China, ou na Rússia. Me parece que o sistema de patentes aqui do Brasil é tão lento, que isso várias vezes desincentiva as pessoas a submeterem um pedido de patente. Em vários casos, vimos um pedido de patentes levar mais de uma década para ser aprovado aqui no Brasil. Tende em conta que uma patente dura apenas vinte anos, a demora de metade desse tempo para ter o pedido de patente aprovado evidencia o porquê de se preferirem outros países para patenteamento de uma invenção, evitando-se com isso o gasto de dinheiro e tempo aqui no Brasil. Acredito que essa parte do universo de propriedade intelectual mereça ser abordada na medida em que a tecnologia da informação se torne ainda mais popular.

Há, finalmente, uma quarta área que acredito seja muito importante sob a perspectiva do direito. Ela se relaciona, de fato, com um novo conjunto de ramos jurídicos que estão começando a surgir a respeito da computação em Revista de Direito, Estado e Telecomunicações, v. 4, n. 1, p. 197-236 (2012) 
nuvem. Há provavelmente três tipos de perguntas que eu vejo em todos os países a respeito da computação em nuvem. Uma delas refere-se à segurança. A segunda diz respeito à privacidade e uma terceira é pertinente a um tipo de soberania da informação, ou jurisdição.

Questões de segurança definitivamente tornaram-se mais importantes, no que tange à computação em rede, pois se pensarem a respeito, há trinta anos atrás, quando o computador pessoal foi inventado, as pessoas falavam as informações - seus extratos bancários ou outras informações pessoais - e elas provavelmente mantinham essas informações em papel, em um arquivo sobre sua mesa. Com o tempo, elas retiraram essas informações de suas mesas e as colocaram no seu desktop armazenadas em seus computadores. No entanto, as pessoas as armazenavam em um disco rígido e isso ainda estava em seus computadores, em suas casas, ou em suas mesas. É claro que com a computação em nuvem, essa informação foi movida para outro lugar em um datacenter e as pessoas querem, por óbvio, ter confiança de que seus dados estão seguros.

A boa notícia é que empresas como a Microsoft e outras como a Amazon e a Google estão certamente investindo em tecnologia de segurança porque esse é um elemento importante na disponibilização desse serviço de computação em nuvem. Tenho para mim que os datacenters e os dados neles armazenados estão mais seguros do que nunca. Todavia, as ameaças a tais dados também estão em ascensão. Temos visto, todos os meses, pessoas investindo em novas tecnologias para tentarem encontrar o caminho até esses dados; ou mesmo lançando ataques malware pela internet; ou praticando novas formas de crimes digitais. Essa é uma questão importante não apenas para empresas do setor privado, como a Microsoft, mas para os governos também. Nós temos visto governos ao redor do mundo atualizando suas leis para assegurar que as ameaças à internet sejam de fato ilegais e que não caiam em lacunas legais, mas sejam tratadas por leis existentes. Temos visto governos criarem novos centros de expertise, que são chamados de equipes de resposta a emergências de computação para monitorar a internet em países específicos e para poder ajudar as pessoas a lidarem com ataques na internet. Nós temos notado que os agentes responsáveis pela aplicação das leis estão fazendo mais no que se refere à colaboração entre países e com o setor privado. Isso se tornou muito importante em um dos mais 
recentes ataques à internet. Portanto, a segurança é a primeira parte da computação em nuvem, em que temos visto o direito evoluir.

Uma segunda área na qual nós temos visto o direito evoluir diz respeito à privacidade. É natural que, se as pessoas transportam suas informações e as armazenam com um terceiro, elas querem estar seguras de que suas informações pessoais serão protegidas de uma forma privada. As empresas prestadoras desse serviço de computação em rede querem saber quem terá acesso as informações, o que as pessoas podem fazer com essa informação e em que circunstâncias -, quando elas precisam notificar os indivíduos que são os donos dessa informação, quando elas precisam de consentimento do indivíduo para fazer uso da informação.

Em algumas partes do mundo, foram adotadas leis de privacidade em diversos formatos nos anos 1980 e nos anos 1990. A União Europeia adotou uma diretiva de proteção de dados. Os Estados Unidos adotou, em meados dos anos 1980, uma lei que é chamada de Lei de Privacidade de Comunicações Eletrônicas [Electronic Communications Privacy Act ECPTA]. Tanto os Estados Unidos, quanto a Europa estão presenciando um movimento de modernização dessas leis, pois, se olharem para as leis que já existem, elas refletem sobremaneira a forma como a tecnologia era utilizada nos anos 1980. Elas agora estão sendo reescritas para refletir a forma como a tecnologia é utilizada na atualidade. Temos visto, em outros países, um esforço adicional para a adoção de novas leis de privacidade, geralmente como parte de um novo arcabouço legal para disciplina da computação em nuvem.

Aqui no Brasil, foi proposto, em 24 de agosto de 2011, um projeto de lei que pretende disciplinar uma variedade de assuntos sobre computação em rede, incluindo a privacidade. Consequentemente, acredito que a privacidade será cada vez mais um campo significativo do direito, que as que estão interessadas em tecnologia da informação e serviços de computação em nuvem deverão estudar.

Finalmente, o último tópico que é realmente relevante sob a perspectiva de computação em nuvem diz respeito à soberania de dados. Uma das características de computação em nuvem é que a informação frequentemente está localizada em um datacenter em um outro país. Sob vários ângulos, se pensarem nas economias de escala que descrevi antes, vale dizer, aquele imenso benefício de tornar a computação mais barata, torna-se, na verdade, Revista de Direito, Estado e Telecomunicações, v. 4, n. 1, p. 197-236 (2012) 
difícil de percebê-lo se tiverem que operar um datacenter em 190 países diferentes. Países de grandes dimensões, como o Brasil, provavelmente terão datacenters, mas mesmo neles será necessário, em alguns casos, que se faça uma cópia de segurança em outros países, ou mesmo que um determinado serviço seja prestado em outro país. Haverá casos em que empresas, no Brasil, fornecerão serviços para indivíduos em outros países da América Latina. Assim, a questão que surge está em que lei aplicar.

Digamos que há um datacenter que é operado aqui no Brasil e ele está fornecendo um serviço para um alguém na Colômbia. Digamos que o indivíduo, na Colômbia, está acessando esse serviço e os dados estão sendo transportados por meio de um cabo que também atravessa a Venezuela. Qual lei é aplicável à proteção da informação daquele indivíduo? É a lei colombiana, porque o indivíduo vive na Colômbia? É a lei brasileira, porque o datacenter está no Brasil? Ou a lei venezuelana também será aplicável em virtude daquela fração de segundos em que a informação é movida entre o Brasil e a Colômbia? Muito bem. Se fizerem essa pergunta hoje, eu acredito que a resposta seja muito, muito clara: ninguém sabe.

Ninguém sabe! E a verdade é que essa é a resposta de hoje não apenas na América Latina. Essa é a resposta na Europa. Essa é a resposta ao redor do mundo. Agora, vocês podem dizer: "se as leis de todo mundo forem similares ou iguais, então o problema se torna menos importante de um ponto de vista prático". Essa é, na verdade, uma das razões pela qual faz muito sentido para os governos trabalharem em conjunto e tentarem adotar leis que sejam razoavelmente parecidas umas com as outras. A partir desse enfoque, essa pergunta se tornará menos complicado de ser respondida de um ponto de vista prático.

Mesmo que se chegue à situação ideal de similitude entre as leis dos diversos países, a questão continua relevante em algumas situações. Deixeme lhes dar um exemplo. Esse é um exemplo que é atual hoje na Europa. Um conjunto países europeus possuem leis que fixam, de fato, para as operadores de datacenter, o período de tempo em que elas devem manter um dado retido, digamos, um dado pessoal. Há uma diretiva europeia que diz que os países podem definir o período de tempo pertinente, desde que ele esteja entre 12 meses e 24 meses. Alguns países disseram que eles queriam que as empresas mantivessem uma informação pessoal retida por 24 meses. Por quê? Porque eles querem que os seus agentes responsáveis 
pela aplicação das leis tenham acesso, em até dois anos, aos dados em casos de acesso a informações relevantes para investigação de um crime. Outros países disseram que eles só querem que os provedores de datacenteres mantenham os dados pessoais retidos por 12 meses e que, após esse período, os dados devem ser destruídos. Por quê? Porque é uma informação sensível e eles não querem que as operadoras a mantenham por um período mais longo. Imaginem que o Brasil diga que os dados devem ser mantidos por 24 meses, e a Colômbia diga que os dados devem ser destruídos após 12 meses. Agora imaginem um cidadão colombiano, que possui informação localizada em um datacenter no Brasil. Como é possível manter os dados por 24 meses e 12 meses ao mesmo tempo? A resposta é que é impossível.

A operadora vê-se em uma situação na qual ela acaba tendo que violar as leis de um país para cumprir com as de outro. Esse é um bom exemplo de como esse assunto pode-se tornar bastante complicado e pode-se tornar na verdade difícil para as operadoras saberem que postura devem adotar.

O caso descrito mostra por que é importante que os governos pensem não apenas em como produzir um conjunto comum de leis substantivas, mas também em como adotar algumas leis de jurisdição. Por exemplo, nós da Microsoft provavelmente defenderemos que os países devem colaborar entre fronteiras, devem criar um arcabouço legal harmônico e tenham reconhecimento mútuo, para que todos possam concordar - desde que os países estejam operando dentro de um arcabouço legal comum -, por exemplo, que a lei em que os dados estão localizados, em outras palavras onde o datacenter está localizado, seja aplicada. Com isso, a Colômbia reconheceria que a lei brasileira seria aplicável.

Quando casos como esses são analisados, pode-se ver como diversas áreas do direito provavelmente tornar-se-ão ainda mais importantes no futuro.

Graduei-me na universidade em 1981 e depois ingressei na Faculdade de Direito, pois nos Estados Unidos vai-se à Faculdade de Direito após sua graduação na universidade. A verdade é que, no início dos anos 1980, nos Estados Unidos, as leis de propriedade intelectual não eram consideradas um campo tão importante. Se a pessoa quisesse realmente se tornar um advogado de patentes, teria que cursar direito de patentes. Estou na Microsoft há 18 anos e eu nunca cursei uma aula de direito de patentes quando eu era um estudante. Hoje isso é impensável. Qualquer pessoa que 
quer ter qualquer relação com tecnologia, provavelmente dirá como estudante de direito: "bem, eu quero cursar direito da propriedade intelectual". É uma disciplina evidentemente muito importante. Está se tornando uma das áreas mais importantes do direito para crescimento econômico em vários países ao redor do mundo. E esse tendência claramente persistirá.

$\mathrm{O}$ direito de propriedade intelectual continua sendo moldado pela tecnologia. Além disso, provavelmente veremos que, daqui a 10 ou 20 anos, as pessoas entrarão na universidade e elas terão interesse em cursar uma disciplina que inclua direito da privacidade. Elas terão o interesse de cursar uma disciplina que inclua direito da segurança. Pode não ser uma disciplina em si mesma, mas será uma aula muito importante e uma disciplina a respeito de direito e tecnologia. Os temas de disciplina jurídica do espectro, da voz sobre IP, e a regulação de telecomunicações continuarão a ser muito importante também. Acredito que, para os objetivos deste público, um dos assuntos mais interessantes será, portanto, como a lei continuará a mudar, ou melhor, eu diria, como nós queremos que ela mude.

Uma das coisas mais estimulantes para um país como o Brasil é como as leis serão escritas nos próximos anos e, depois, como elas serão reescritas durante o transcurso de suas carreiras profissionais. Eu acredito que uma das coisas mais interessantes sobre ser um estudante hoje é saber que, durante o transcurso de suas carreiras profissionais, vocês terão oportunidade de contribuirem com a forma como a lei mudará aqui no Brasil. Talvez vocês contribuam, alguns de vocês, trabalhando no governo. Talvez vocês contribuam representando clientes, ou trabalhando para empresas, ou por meio de atividades na Ordem dos Advogados. Mas se vocês estão interessados nesse campo do direito, quase certamente terão a oportunidade de contribuir com a forma como ela mudará no tempo.

Tendo em vista como essa tecnologia alterará a economia, bem como considerando a taxa de modificação da própria tecnologia, esse é um campo realmente interessante para abertura de oportunidades de contribuição. Eu espero voltar aqui nos próximos anos e ver o que vocês fizeram, individualmente e coletivamente, para avançar essa área do direito.

Deixem-me, então, parar por aqui. Deixem-me dizer muito obrigado e vamos abrir para perguntas e para conversar sobre qualquer assunto que 
vocês tenham interesse, seja sobre o que eu estive falando ou sobre outros assuntos.

Prof. Márcio Iorio Aranha:

Muito obrigado, Sr. Brad Smith. O senhor certamente nos deu uma visão privilegiada do que está acontecendo na nuvem. O tema é rico em derivações e pormenores, de forma que espero que considere voltar à universidade, no futuro, para preencher esse vazio.

Estamos muito satisfeitos de recebê-lo aqui e de ouvir uma apresentação de um executivo-chave da Microsoft. Sem sombra de dúvidas, essa apresentação abriu nossos olhos para diversas e complexas questões jurídicas e assuntos relacionados à internet e à computação em nuvem. Como coordenador do Núcleo de Direito Setorial e Regulatório, falo aqui muito em nome do grupo de estudos em direito das telecomunicações. Há muitos alunos interessados nesse aspecto do direito e eu tenho certeza de que o meu papel aqui não é preencher o tempo remanescente, mas endereçar algumas questões provocativas em tópicos de interesse para que o Sr. Brad Smith possa falar mais a esse respeito.

Com esse fim, eu tenho perguntas minhas, mas eu gostaria de abrir a todos aqui para participarem desta sessão de perguntas e respostas.

Bom, eu tenho uma pergunta. Falarei em português a partir de agora para iniciarmos essa segunda parte do evento com perguntas e respostas e para incentivar mais perguntas por parte dos estudantes.

Situando um pouco o que foi dito aqui sob o ponto de vista de regulação, sob o ponto de vista das diversas áreas de direito que nós temos estudado, há uma comparação que se costuma mencionar quando se trata da computação em nuvem no sentido de que ela encarnaria aquele avanço que a revolução industrial esperava da energia, e que, no âmbito da revolução informacional, da sociedade da informação, nós esperamos da computação em nuvem.

Portanto, a apresentação certamente não veio para tratar da questão de computação em nuvem, que diz respeito ao interesse empresarial, mas veio até nós para abordar muito mais do que isso. Ela é um dos aspectos centrais da revolução informacional, que temos estudado nos grupos de pesquisa setoriais. 
Com base nisso, eu gostaria de lançar uma questão. Tenho várias questões, mas acredito que todos temos direito a usufruir da presença do Sr. Brad Smith aqui. Nos interessa muito ter o ponto de vista de quem opera, e quem tem essa visão diferenciada sobre o dia-a-dia do tratamento contratual entre os servidores de computação em nuvem - os cloud computing servers - e terceiras pessoas, principalmente no que diz respeito às cláusulas contratuais que mais incomodam ou que sejam consideradas as mais relevantes, com todo o problema de conflito de jurisdição que isso gera, mas tendo em mente esse diferencial, que é a computação em nuvem. Se o senhor puder desenvolver um pouco esse assunto para nossos estudantes...

Sr. Brad Smith:

O que eu posso dizer na prática é que o que nós estamos vendo, não surpreendentemente, no contexto de computação em nuvem no qual essas cláusulas aparecem, é que os consumidores querem saber onde seus dados estão localizados, como eles serão protegidos, e como esses dados serão utilizados.

Então, de uma forma muito prática, nós estamos achando que consumidores em várias partes do mundo, especialmente em grandes empresas, desejam às vezes ter cláusulas contratuais que remetam a esses assuntos, em particular. Isso provavelmente está mais destacado na Europa. Hoje nós estamos vendo consumidores europeus mencionando o assunto, porque há um foco em direito da privacidade na Europa, há 30 ou 40 anos. Então é lá que nós estamos vendo esse assunto provavelmente de forma mais intensa.

Nós na verdade fizemos um trabalho com um grupo de acadêmicos em Londres que estão analisando cláusulas contratuais em toda a indústria para descobrir se há alguma tendência geral. A primeira tendência que foi notada é que de tempos em tempos os consumidores desejam uma espécie de dispositivo contratual sobre em qual datacenter seus dados estarão armazenados. Se há uma escolha entre datacenters, eles desejam negociar onde seus dados estarão localizados. Em nossa perspectiva, isso às vezes faz sentido, às vezes faz menos sentido, simplesmente porque, eu acho, o que é realmente importante para os consumidores é que seus dados estejam armazenados de forma segura. E o que isso normalmente significa para os 
consumidores corporativos é que nós tenhamos uma cópia de seus dados em dois lugares diferentes. Você sabe, para que exista um back-up de seus dados.

Vocês sabem, a maior ameaça hoje seria, por exemplo, se algo acontecesse a um datacenter. Se houvesse um incêndio no datacenter, ou se houvesse um terremoto ou um tsunami. E eu tenho que dizer que os recentes eventos no Japão, eu acredito, deixaram as pessoas ao redor do mundo pensando de forma mais geral porque eu acho que a primeira reação dos consumidores era: "nós queremos nossos dados em um datacenter local, e se houver back-up, bem, tudo bem, então faça isso em um datacenter do outro lado da rua". Bem, o que as pessoas viram no Japão é que se houver um terremoto de um lado da rua, o terremoto também estará do outro lado da rua. Então você estará melhor, algumas vezes, se os seus dados estiverem duplicados em um datacenter que está localizado em outro país. Então, você sabe, nós estamos vendo que um certo nível pragmático estabelece o que os consumidores desejam.

A segunda coisa que nós estamos vendo é um conjunto de questões contratuais que às vezes aparecem em torno de segurança. Como vocês sabem, há certos padrões ISO altos e outros padrões internacionais sobre segurança para datacenters. Como uma empresa, a Microsoft adotou o padrão internacional ISO. Nós adotamos vários outros padrões similares. Nós estamos vendo que os consumidores às vezes perguntam sobre esses padrões e eles querem vê-los refletidos nos acordos contratuais também.

Há uma terceira área que às vezes nós percebemos que os consumidores estão interessados na perspectiva contratual, que é um conjunto de obrigações que ocorreriam caso os agentes aplicadores do direito viessem e tentassem apresentar um mandado judicial ou uma intimação em um provedor datacenter. Digamos que há um banco e esse banco tem alguns dados bancários em um datacenter. No passado, se os dados estivessem no servidor do banco, então o governo obviamente deveria cumprir o mandado judicial, notificação ou intimação no próprio banco. Bem, ao contrário, se os dados estão localizados em um datacenter, eles podem vir e cumprir o mandado no próprio operador do datacenter.

Nós normalmente recebemos a oferta de celebrar com o banco uma cláusula contratual dizendo que, na máxima extensão possível, nós não cumpriríamos o mandado sem antes informar o banco, para que o banco 
possa pedir para os seus advogados analisarem a questão e ter a oportunidade de apresentar quaisquer objeções que eles tenham. Pode haver alguns lugares em que isso não seja possível. Que a lei local não nos dê essa oportunidade. Mas nós realmente gostaríamos de assegurar que nossos consumidores tenham todos os meios legais que lhes são assegurados e nós tentamos aplicar isso em nossos contratos. Então, esses são alguns diferentes exemplos de, basicamente, cenários concretos que estão ocorrendo em razão desses novos tipos de serviços, com novas questões contratuais e novos tipos de termos contratuais.

Questão da audiência:

Eu sou um engenheiro da computação. Também sou um estudante aqui na UnB, um estudante de direito. Eu trabalho para o equivalente da FCC no Brasil, que é a Anatel. Então, eu tenho duas perguntas. Primeiro, eu gostaria de saber o seguinte: na semana passada, a Verizon ajuizou uma ação judicial contra o FCC sobre neutralidade de rede. Eu gostaria de saber qual é a posição da Microsoft no que tange à neutralidade de rede. E a segunda questão é: a Microsoft é obrigada a cumprir o Patriot Act?

Sr. Brad Smith:

São duas questões muito interessantes. A primeira refere-se ao fato de que a neutralidade de rede tornou-se um assunto importante nos Estados Unidos e é um assunto que tem sido considerado em um conjunto de outros países, incluindo o Brasil. A Microsoft, como empresa, apoiou bastante o acordo que a Federal Communications Commission, ou FCC, adotou ao final nos Estados Unidos.

Esse assunto foi debatido por cerca de uma década nos Estados Unidos e então o FCC finalmente adotou novas regras no ano passado. Essas regras, em nossa ótica, de certa forma estabelecem um equilíbrio a tempo de assegurar que a maior parte dos serviços possam ser oferecidos livremente na internet, e sem que sejam aplicadas diferentes taxas por eles. Não há discriminação. Mas também há a oportunidade, de uma forma razoável, para que as empresas de telecomunicações, os operadores da rede, em certas circunstâncias, imponham taxas desde que eles o façam de uma forma que 
cumpra com as tradicionais normas do FCC sobre quando é apropriado discriminar entre serviços.

Nós notamos que há a necessidade real, nos Estados Unidos e em outros lugares, de que os operadores da rede sejam capazes de empregar modelos de negócios que os tornem capazes de continuar investindo em melhoria de suas infraestruturas. Então pode haver ocasiões em que haverá necessidade de impor taxas para continuar a aumentar os fundos necessários para investir, e nós achamos que as normas de neutralidade de rede adotadas nos Estados Unidos parecem atender a isso. Quando da adoção do acordo, a maior parte da indústria, normalmente, o apoiava. Você sabe, a AT\&T, uma das maiores operadores de rede, o apoiava. Empresas como a Microsoft, que estão mais no nível de serviço (no sentido de oferecer serviços pela Internet), o apoiava. Empresas como a Google e outras passaram a apoiá-lo também. Então esse é o nosso ponto de vista.

A respeito de sua segunda pergunta, o que é interessante é: a maior parte dos países, incluindo os Estados Unidos, possui um conjunto de requisitos judiciais de acordo com os quais eles, em certas circunstâncias, insistem que sua lei é aplicável a qualquer empresa que está fazendo negócio dentro de sua fronteira.

Há um precedente que foi adotado pelos Tribunais dos Estados Unidos há alguns anos chamado caso do Banco da Nova Escócia (Bank of Nova Scotia). O Banco da Nova Escócia era um banco sediado no Canadá - Nova Escócia, como vocês devem saber, é uma província do Canadá - e o Banco da Nova Escócia possuía uma filial nas Ilhas Cayman. O Banco da Nova Escócia também estava fazendo negócio nos Estados Unidos. Então, as Ilhas Cayman possuíam uma norma que dizia que se você colocasse seus registros bancários nas Ilhas Cayman, as Ilhas Cayman não entregariam seus registros bancários para nenhuma outra agência legal de qualquer país. Então, o Banco da Nova Escócia tinha registros bancários nas Ilhas Cayman. Esses registros bancários tornaram-se importantes para uma investigação nos Estados Unidos, e então o Banco da Nova Escócia foi processado. O Banco da Nova Escócia disse: "nós não temos que entregar esses registros. Eles estão nas Ilhas Cayman e as Ilhas Cayman os protegem." Os Tribunais dos Estados Unidos disseram, ao fim, que eles não se importavam. O Banco da Nova Escócia estava fazendo negócios nos Estados Unidos sob a Lei dos 
Estados Unidos e a Lei dos Estados Unidos alcançava aqueles registros bancários.

Isso, de forma resumida, explica a questão do Patriot Act, aos quais as pessoas normalmente se referem, pois o Patriot Act é uma outra lei que às vezes alcança dados que existem fora dos Estados Unidos. Em certa medida, acredito eu ser claro que, tendo em vista a doutrina do Banco da Nova Escócia, qualquer empresa que esteja fazendo negócio nos Estados Unidos pode, em determinadas circunstâncias, ser requerida a entregar informação a quem aplica o direito nos Estados Unidos. Não importa se é uma empresa americana, não importa se é uma empresa brasileira. Se a empresa estiver fazendo negócios nos Estados Unidos, ela pode estar sujeita à lei dos Estados Unidos. Eu acho que alguém é capaz de descobrir que a mesma solução existe nas leis de vários outros países também.

O que nós fazemos, de maneira pragmática, é em primeiro lugar ajudar as pessoas a entenderem que apenas raramente haverá um conjunto de circunstâncias nas quais isso poderá ocorrer com suas informações. Não é todas as vezes que as pessoas acordam e têem vontade de obter informação. Você precisa ter uma base legal muito bem estabelecida. As bases legais são muito restritivas e é necessário que exista uma ordem judicial e que a ordem seja apropriada.

A outra coisa que nós temos normalmente feito, como uma empresa, remete ao assunto sobre o qual eu estava falando antes. Nossa preferência é alertar nossos clientes, para que nossos clientes saibam quando há uma intimação ou um mandado judicial que será apresentado; com isso, nossos clientes terão a oportunidade de dizer "sim, nós estamos confortáveis com isso", ou os clientes terão a oportunidade de entrar em juízo e protestar contra isso. No ambiente corporativo, normalmente é muito fácil de enxergar isso funcionando. Acredito, entretanto, que o que nós realmente estamos tentando fazer é: em primeiro lugar, ajudar a assegurar que as pessoas entendam quando essas questões surgem e quando elas não surgem, o quão significativamente isso será, do ponto de vista prático; e depois, em segundo lugar, assegurar que as pessoas estejam, em sua máxima extensão, realistas e razoáveis, capazes de saber o que está ocorrendo com seus dados, e em posição de proteger seus direitos. 
Questão da audiência:

A palestra tem sido muito interessante. Eu tenho duas perguntas. A primeira, aproveitando a pergunta sobre neutralidade de rede, eu gostaria de escutar um pouco mais e ter sua impressão da interface entre neutralidade de rede e computação em nuvem. Em especial, o quão comprometida está a Microsoft em evitar discriminação entre usuários enquanto eles estão utilizando computação em nuvem e como o senhor acha que os reguladores devem atuar para evitar essa discriminação.

A segunda pergunta envolve a operação Google/Motorola. Eu gostaria de escutar um pouco sobre como o senhor acredita que essa operação afetará a capacidade da Microsoft de colocar seu software e competir de forma efetiva no mercado de tablets e smartphones.

Sr. Brad Smith:

Boas perguntas. Vocês fazem ótimas perguntas, por sinal. A primeira pergunta, sobre neutralidade de rede: eu acho que nós diríamos basicamente o seguinte para os primeiros pontos. Em primeiro lugar, da perspectiva de computação em rede, haverá uma quantidade muito maior de serviços oferecidos pela internet e muitos desses serviços são serviços que estão em sua infância ou não tão difundidos hoje como os serviços que são tradicionalmente disponibilizados por operadoras de telefone ou outros operadores de rede por meios diferentes.

Pode-se pensar no telefone ou em como o Skype pode na verdade replicar a função para a qual as pessoas utilizam suas redes de telefonia. Nós podemos pensar sobre a televisão tornando-se um dispositivo conectado à internet. É muito fácil imaginar que a programação televisiva será disponibilizada também pela internet no futuro. Em primeira instância, não surpreendentemente, já que nós mesmos somos provedores de serviços, nós estamos muito entusiasmados com um quadro regulatório no qual seja fácil oferecer serviços. Eles são baratos e não há muita discriminação entre serviços. Então, em geral, nós apoiamos um tipo de panorama como o que existe tipicamente hoje.

Se se tem uma conexão à internet, pode-se conectar qualquer aparelho que se desejar a ela e a qualquer serviço disponibilizado na internet. E você 
não tem que pagar mais ou menos dependendo de qual aparelho você está utilizando. Você não tem que pagar mais ou menos baseado em qual serviço que estiver acessando. Nós diríamos que aí há a necessidade de operadores de rede começarem a cobrar e a discriminar entre serviços, digamos, porque alguns serviços utilizam muito mais banda que outros serviços. Nesse caso o mais importante é que os agentes aplicadores do direito garantam que essa discriminação não levará a impactos anticoncorrenciais na internet. Nós, da Microsoft, ficaríamos preocupados, por exemplo, se houvesse uma abordagem que impusesse taxas e essas taxas acabassem na prática discriminando contra serviços que possuem uma participação de mercado menor, porque nós acreditamos que isso pode realmente desincentivar a inovação e desincentivar a concorrência. Por isso, o princípio número um que nós replicamos e o que foi adotado pela Federal Communications Commission, nos Estados Unidos: operadores de rede devem assegurar que suas taxas não possuam impacto anticoncorrencial. Essa seria a nossa posição, em geral, sobre a questão da neutralidade de redes.

A operação Google/Motorola, em nossa perspectiva, levanta uma preocupação muito específica, mas muito importante. Ela se relaciona com a questão de patentes. As patentes tornaram-se uma questão muito importante, como vocês devem ter visto, no ambiente móvel. Houve empresas que possuíam patentes que entenderam que elas foram infringidas - a Microsoft é uma dessas empresas; a Apple é uma dessas empresas; a Oracle é uma dessas empresas. A Microsoft é uma empresa que está celebrando contratos de licenciamento para licenciar nossas patentes a empresas no ambiente móvel. Já na na semana passada, nós anunciamos um acordo com a Samsung. Nós anunciamos sete desses acordos nos últimos três meses, que remontam a um grande acordo celebrado com a HTC no ano passado. Quando a Google anunciou que eles estavam adquirindo a Motorola Mobility, eles basicamente disseram que estavam adquirindo a Motorola por dois motivos. O primeiro era para comprar uma empresa que estava produzindo telefones, smartphones, porque a Motorola é uma fabricante líder de smartphones. E o segundo, eles estavam comprando a Motorola para adquirir o portfólio de patentes da Motorola.

O assunto com que nós estávamos preocupados é o seguinte: durante anos, a Motorola celebrou inúmeros acordos com entidades de padronização, pelos quais a Motorola comprometeu-se com essas entidades 
de padronização a licenciar patentes que são necessárias - que são essenciais - para certos padrões, no que nós costumamos chamar termos RAND (termos razoáveis e não discriminatórios) [reasonable and nondiscriminatory terms (RAND) ou fair, reasonable, and non-discriminatory terms (FRAND)]. Uma área em que isso é importante é no ambiente 802.11. A Motorola comprometeu-se com certas entidades de padronização que ela licenciaria esses padrões que são essenciais para implementar a tecnologia 802.11 para Wi-Fi em termos RAND.

Da mesma forma, a Motorola, há alguns anos, adquiriu uma empresa chamada General Instrument. A General Instrument era e é uma líder na categoria set-op box. A General Instrument e depois a Motorola fizeram compromissos RAND similares para certas tecnologias de vídeo que são essenciais para os padrões de vídeo que são utilizados de forma ampla por todas as pessoas que assistem a um vídeo pela internet.

Se você tem uma tecnologia Wi-Fi e uma tecnologia de vídeo, ambas são atingidas por esses compromissos RAND, que são compromissos-chave realizados com entidades de padronização. Ora, sempre que a Microsoft adquiriu uma empresa que realizou compromissos de padronização, uma das primeiras atitudes que nós tomamos foi que afirmarmos publicamente que nós continuaríamos cumprindo todos os compromissos de padronização em termos RAND. No entanto, faz cerca de um mês e meio desde que a Google anunciou que estaria comprando a Motorola Mobility, mas ela ainda não fez uma declaração pública desse tipo. Para nós, da Microsoft, a grande pergunta é: a Google cumprirá esses compromissos que foram firmados com entidades de padronização ao redor do mundo para tecnologias que são fundamentais para a saúde da internet, em bases mundiais? Se não cumprir, então nós teríamos de dizer que há uma questão relavante para a qual os agentes aplicadores do direito devem olhar, no contexto de se analisar se a compra da Motorola Mobility pela Google deve, de fato, ser aprovada.

Então, na semana passada o Departamento de Justiça dos Estados Unidos apresentou o que se denomina como segundo pedido, nos termos da Lei Hart-Scott-Rodino [Hart-Scott-Rodino Antitrust Improvements Act of 1976]. Essa é a lei que o Departamento de Justiça dos Estados Unidos cumpre quando está analisando uma aquisição para fins concorrenciais. É sabido, hoje, que vários agentes aplicadores do direito ao redor do mundo 
olharão para essa questão. Nós achamos que essa é uma questão importante para eles analisarem.

Prof. Márcio Iorio Aranha:

Eu tenho uma pergunta aqui que me foi passada por escrito. O Sr. Brad Smith acredita que seja possível a aplicação de dispositivos legais como o Global Internet Freedom Act para se regularem as questões relativas à computação em nuvem. Ou seja, os acordos e tratados internacionais seriam aptos a regular essa matéria? Complementando o que foi escrito, a disciplina internacional sobre o tema de acordos internacionais tem coberto alguns setores de interesse e alguns problemas relacionados à computação em nuvem?

Sr. Brad Smith:

$\mathrm{Eu}$ acredito que essa seja uma questão muito interessante porque se pensarem a respeito da internet como um meio, esse meio é novo e mundial. Essas são duas de suas características e, portanto, torna-se realmente interessante e importante pensar a respeito de qual lei melhor a direciona, especialmente quando nós pensamos sobre o seu caráter mundial. Nós tendemos a ver que é necessária uma combinação de leis novas e leis velhas, juntas, para direcionar esses tipos de questões que estão sendo levantadas a respeito da internet.

Quando nós pensamos a respeito de leis novas, faz-se uma pergunta muito boa: nós podemos ter um tratado mundial disciplinando esses assuntos? Acredito que, sob diversos aspectos, seria útil ter-se um tratado mundial para direcionar algumas dessas questões como soberania de dados e segurança e privacidade e outros. O problema com um tratado mundial é que, com 190 países ao redor do mundo, é na verdade extraordinariamente difícil fazer com que seja aceito um tipo de instrumento legal mundial. Assim, acredito que, a nossa perspectiva é que isso deve ser feito em etapas. Não se pode começar desejando que todos os governos do mundo estabeleçam um tratado mundial. Deve-se começar por fazer com que os principais países ao redor do mundo aprovem leis próprias, quiçá de uma forma em que eles falem uns com os outros para que haja um grau razoável 
de similaridade. Depois eles podem aplicar suas leis e uma vez que você tenha os principais governos ao redor do mundo com alguns anos de experiência prática com um conjunto de leis similares, torna-se possível harmonizar as leis de forma regional e depois se torna possível construir uma rede com as Nações Unidas, a Organização Mundial do Comércio ou algum outro organismo de abrangência mundial.

Então eu acho que neste momento, um tratado global ainda está bastante distante. Eu acredito que daqui a trinta anos, provavelmente exista um. Daqui a vinte anos, talvez. Em dez anos, provavelmente não. Isso provavelmente é algo que levará entre dez e trinta anos.

Agora, o outro lado disso, que é muito interessante, reside no aspecto prático para advogados de como utilizar e como adaptar as leis existentes para que as leis existentes possam ser utilizadas para disciplinar alguns dos problemas práticos que surgem. Essa é uma área que acredito haja muito espaço para inovação jurídica e, em particular, muito espaço para uma interessante colaboração entre engenheiros e advogados.

O professor Márcio referiu-se anteriormente ao quão interessante é ter ambos, uma experiência em engenharia e jurídica. $\mathrm{Na}$ verdade poucas pessoas possuem ambas. Eu acredito que se uma pessoa tem experiência em engenharia e direito, ela estará muito bem posicionada para o futuro. No entanto, a boa notícia é que mesmo que vocês não tenham uma dupla formação, se vocês tiverem apenas uma das duas, há hoje mais oportunidades para advogados e engenheiros trabalharem de uma forma realmente criativa.

Vou contar uma história sobre o que os nossos colaboradores realizaram no ano passado. Nós temos um grupo que é parte de nosso departamento que é chamado de unidade de crimes digitais. A unidade de crimes digitais trabalha na Microsoft para auxiliar a investigação e colaboração com aplicadores do direito em crimes digitais, como é de se esperar. O grupo possui advogados, possui técnicos jurídicos [paralegals] e possui engenheiros, bem como outras pessoas que trabalham em conjunto como um único grupo. No início deste ano, eles estavam envolvidos em uma investigação sobre a maior operação de spam no planeta. Existia um único grupo que estava gerando até trinta bilhões de mensagens de spam todos os dias. Esse único grupo estava gerando o que era estimado entre 40 e $60 \%$ da quantidade total de spam no mundo.

Revista de Direito, Estado e Telecomunicações, v. 4, n. 1, p. 197-236 (2012)

DOI: https://doi.org/10.26512/lstr.v4i1.21579 
O que a unidade de crimes digitais fez foi se concentrar na técnica que eles estavam utilizando para gerar spam. Em síntese, a forma como as pessoas estão envolvidas em ameaças muito difundidas pela internet, hoje, é frequentemente por intermédio do que é chamado de botnet. O termo designa basicamente uma técnica de engenharia que, de fato, captura vários e vários computadores pessoais. Se um computador pessoal estiver conectado à internet e não possua proteção de segurança adequada - se ele não possui um firewall instalado - é, infelizmente, possível - é até mesmo provável - que alguém invada aquele computador, e embora sem conhecimento por parte do usuário do computador, ao mesmo tempo em que uma pessoa estiver utilizando o computador para o seu trabalho diário, aquele computador também pode estar sendo utilizado para enviar várias mensagens de spam. Normalmente, o usuário do computador sequer sabe o que está acontecendo. Várias vezes isso acontece em universidades ao redor do mundo, porque vocês têm vários estudantes com computadores que estão conectados, professores, funcionários em diferentes partes da universidade. Esse botnet em questão - era um botnet chamado Rustock - literalmente capturou dezenas de milhares de computadores ao redor do mundo para enviar esses spams. Tudo isso é controlado por um número reduzido do que é chamado de computadores de comando e controle. Esses são computadores servidores que são igualmente capturados para então serem utilizados para o envio de mensagens aos computadores pessoais lhes determinando que enviem as mensagens spam, bem assim para quem enviar tais mensagens e o que deve constar delas.

Assim, enquanto há dezenas de milhares de computadores pessoais que estão sendo utilizados para isso, o número de computadores de comando e controle é tipicamente de algumas dúzias ou talvez até mesmo uma dúzia. Portanto, o que nossos engenheiros fizeram foi identificar o endereço de protocolo de internet - os endereços IP -, dos computadores de comando e controle ao redor do mundo que estavam sendo utilizados para controlar esse botnet. Essa foi a inovação da engenharia. Nós estávamos cientes de que havia cerca de dez servidores pelos Estados Unidos que estavam sendo utilizados para isso. Havia um servidor na Holanda que estava sendo utilizado para isso e havia um servidor na China.

A partir daí tivemos que implementar a inovação jurídica, pois a pergunta passou a ser: "como nós podemos agir de forma efetiva para 
alcançar esses servidores de comando e controle e desligá-los da internet?”. Há várias formas que se utilizam em geral de novas leis que foram promulgadas nos últimos dois anos nos Estados Unidos. Mas há também uma lei antiga: uma lei que foi promulgada em 1946 obviamente antes da internet ter sido sequer imaginada. Essa é uma lei de registro de marcas chamada de Lanham (Trademark) Act. Trata-se de uma lei de registro de marcas que é uma das mais importantes leis de registro de marcas dos Estados Unidos. Basicamente, como ocorre com todas as leis de registro de marcas, ela diz que é ilegal a utilização de marcas por alguém sem permissão. Por que isso era relevante? Porque várias dessas mensagens spam estavam utilizando as marcas de outras empresas. Por exemplo, algumas mensagens de spam estavam sendo utilizadas para vender cópias falsificadas do Microsoft Office. Havia ali, portanto, uma violação à marca, de acordo com o Lanham Act. Elas também estavam sendo utilizadas para vender Vioxx, que é uma marca da Pfizer Corporation.

Consequentemente, a junção das inovações jurídica e tecnológica foi a seguinte: nossos advogados ajuizaram uma ação em um tribunal, em Seattle, Washington, o Tribunal Federal dos Estados Unidos em Seattle, Washington, e o primeiro caso foi chamado de Microsoft vs. John Doe [João Ninguém]. Nos Estados Unidos, se há fundamento legal para uma ação, mas ainda não se sabe quem é o réu, em alguns casos, pode-se chamar a parte desconhecida de John Doe. Assim, nós ajuizamos essa ação e, ao ajuizar essa ação, nós fomos capazes de alcançar os provedores de internet, porque nós éramos capazes de ver pelo endereço dos protocolos de internet qual provedor de internet era responsável pelos diferentes computadores de comando e controle. A partir daí, fomos capazes de obter mandados judiciais para apresentá-los a esses Provedores de Serviço de Conexão à Internet (PSCI) [Internet Service Provider (ISP)], para que nós fôssemos informados da localização exata desses computadores, ou seja, a localização física, bem como na propriedade de quem eles estavam operando. Com base nesses mandados judiciais, nós então pudemos ir aos agentes federais [Federal Marshalls], que fazem parte dos agentes aplicadores do direito nos Estados Unidos e, em um único dia, no dia 17 de março, na Holanda, nos Estados Unidos e na China, os agentes basicamente desconectaram cada um desses servidores de comando e controle. Eles os desligaram, os desconectaram da internet e os apreenderam.

Revista de Direito, Estado e Telecomunicações, v. 4, n. 1, p. 197-236 (2012)

DOI: https://doi.org/10.26512/lstr.v4i1.21579 
A essa altura, os especialistas em engenharia na indústria estavam monitorando a quantidade de spam que estava saindo desse botnet: algo em torno de 25 bilhões por dia, 26 bilhões por dia, 24 bilhões por dia, até que, no dia 17 de março, zero. A operação inteira foi reduzida a zero. Assim, fomos capazes de interromper a operação inteira desse botnet, acabar com todo aquele spam, e uma vez que nós tínhamos posse dos computadores de comando e controle, nós fomos capazes de identificar cada um dos computadores pessoais para os quais eles estavam enviando mensagens e então nós pudemos enviar novas mensagens a esses computadores pessoais, para informar aos seus usuários seus computadores estavam infectados, fornecendo instruções sobre como eles poderiam limpar os seus computadores para que eles não mais tivessem esse malware em suas máquinas. Nós também informamos como eles poderiam ligar seus firewalls, para que eles não fossem infectados por um segundo dispositivo.

Enfim, o que eu acredito seja realmente interessante nesse caso é que as pessoas pensam - corretamente - que nós precisamos de várias novas leis para solucionar esses problemas. No entanto, um dos aspectos mais interessantes sobre tudo isso é possibilidade de encontrarmos novas formas de utilização de leis antigas, nesse caso, uma 1946. Isso exemplifica o quão interessante é esse novo ramo do direito, pois ele permite que as pessoas trabalhem, nesse caso com engenheiros e digam "aqui está um problema imenso; quais são as novas formas que nós podemos pensar para resolvêlo?”. Há vezes em que se pede para que uma nova lei seja aprovada, mas o que realmente importa é fazer com que os advogados pensem de forma realmente criativa, sem fronteiras. É incrível a quantidade de novas coisas que as pessoas podem fazer a partir daí. Trata-se de uma área verdadeiramente interessante de trabalho.

Prof. Márcio Iorio Aranha:

Nossa Faculdade é repleta de engenheiros que também são advogados. Na verdade, o atual Presidente do Tribunal de Contas da União foi estudante desta universidade e ele é um advogado e um engenheiro. Aparentemente, estamos no caminho certo. Nós temos mais uma pergunta da plateia. 
Questão da audiência:

Eu gostaria de saber a razão pela qual a Microsoft juntou-se ao consórcio que adquiriu as patentes da Nortel no mês passado, porque vejo que as empresas estão utilizando as patentes como um escudo - você não me processa, ou eu te processarei - mais do que para proteger inovação. Por isso a Google comprou a Motorola Mobility.

Sr. Brad Smith:

Ótima pergunta. Em primeiro lugar, eu na verdade diria que acredito que as pessoas estão utilizando patentes para promover inovação, ainda que o que você acabou de descrever esteja sendo dito frequentemente, ou seja, que as pessoas estão utilizando as patentes para o objetivo de se protegerem de ações. Deixe-me lhe apresentar uma perspectiva sobre o tema. Quando se tem uma empresa que ingressa em uma nova área - um novo campo da tecnologia -, a não ser que esse campo seja totalmente novo, já existirão outros trabalhando nele. Dessa forma, em geral, quando se ingressa nesse novo campo, é necessário pensar: "como eu vou enfrentar as patentes que já existem nesse campo?".

Uma das formas de se enfrentar o problema é desenvolver sua tecnologia ao redor da patente. Quando a Microsoft, com nosso Xbox, viu o sucesso do Nintendo Wii, nós dissemos: "isso é realmente importante e nós temos que encontrar um jeito de os usuários interagirem com esses aparelhos sem terem que utilizar o controle tradicional." Então nós pensamos: nós podemos copiar o Wii. Se nós copiássemos o Wii, nós teríamos que licenciar as patentes da Nintendo, porque a Nintendo possui patentes do Wii. Assim, em primeiro lugar nós teríamos que descobrir se a Nintendo queria licenciar as patentes - havia uma boa chance de que ela não quisesse - ou talvez ela quisesse, e nesse caso elas provavelmente seriam caras. Claro, eles inventaram isso e se todos pudessem copiar, eles provavelmente não teriam incentivo para continuar investindo em invenções similares no futuro. Nós decidimos, no caso do Wii, que nós iríamos desenvolver nossa tecnologia e projetar o Xbox ao redor dele. E isso foi parte do que nos levou a inventar o Kinect. Francamente, essa é o primeiro efeito das patentes. À medida que é dado ao inventor uma patente exclusiva, isso incentiva todas as outras 
pessoas a falarem "vou fazer a mesma coisa, vou copiar mas eu pagarei royalties, ou eu vou ser criativo e inovar e criar ao redor disso."

Agora, na maior parte das vezes, quando um novo campo é desbravado, o seu desejo é utilizar muitas das patentes que os outros possuem. Você deseja inovar, mas você deseja inovar, de certa forma, apoiando-se nos ombros das outras pessoas.

A Microsoft entrou no Mercado corporativo, no Mercado de servidores, nos anos 1990. Naquele tempo, havia várias empresas que estavam no mercado de servidores antes de nós. Empresas como IBM, Digital Equipment e Sun Microsystems e uma empresa chamada SGI. Nós, então, pensamos: "nós, na verdade, desejamos utilizar várias dessas invenções". Fomos, então, essas empresas e dissemos: "nós vamos pagar por uma licença. Você licenciaria essas patentes para nós?". Na maior parte das vezes, as empresas estão dispostas e licenciar suas patentes em troca do que elas entendem que seja um royalty adequado. Ao final, nos últimos dez anos, a Microsoft pagou cerca de 4,5 bilhões de dólares para licenciar patentes de outras empresas da indústria.

Se se perguntarem se 4,5 bilhões de dólares não é muito; se esse investimento faz sentido, eu lembraria a vocês que a Microsoft gasta mais em pesquisa e desenvolvimento do que qualquer outra empresa no mundo. Neste ano nós gastaremos 9,6 bilhões em pesquisa e desenvolvimento. Assim, durante uma década, nós gastamos cerca de 90 bilhões de dólares para gerar as nossas próprias invenções e nós gastamos cerca de 4,5 bilhões de dólares para licenciar patentes do resto da indústria. Com isso, os nossos custos com licenciamento são cerca de $5 \%$ do que nós gastamos com pesquisa e desenvolvimento. Me parece que esse é um bom ponto de equilíbrio. Ele permite que nós nos apoiemos nos ombros dos outros.

Muito bem. Como isso se relaciona com sua pergunta? De certa forma, quando a Google criou o Android, eles entraram em um mercado no qual diversas outras empresas já estavam atuando, pois o Android é, obviamente, um sistema operacional de computador que é executado em um telefone ou em um tablet. Se eles tivessem feito o que a Microsoft fez, ou o que outras empresas na indústria tipicamente fizeram, eles teriam feito uma de duas coisas. Ou eles diriam: "nós vamos desenvolver ao redor das patentes de todas os demais" ou eles diriam "nós vamos licenciar as patentes dos outros e pagar por esse licenciamento e, então, nós poderemos usá-las". 
A Google não fez nenhuma dessas duas coisas. Eles basicamente disseram e o disseram publicamente: "nós pensamos que a questão das patentes é algo que deve ser enfrentado pelo fabricante do dispositivo. No mercado de telefonia, são geralmente eles que cuidam desses assuntos". Essa nunca foi nossa abordagem. Nós sempre afirmamos para as pessoas que possuem computadores pessoais: "se nosso software infringe uma patente, isso não é seu problema, isso é nosso problema. Nós queremos que as pessoas nos processem, não a vocês." Se isso ocorrer, nós licenciamos a patente. Se eles o processarem ao invés de nos processarem, nós lhe indenizaremos, nós defenderemos a ação, nós pagaremos por qualquer julgamento. E de fato, o que normalmente aconteceu foi que nós iniciamos nossas próprias ações, sob o que é chamado de procedimento de ação declaratória, para que ficasse claro que nós éramos a parte interessada.

A Google, em minha opinião, fez algo que é muito pouco convencional, quase sem precedente e, em muitas formas, criou uma dinâmica muito interessante para a indústria, à medida que, não obstante eles terem dito que apoiariam seus parceiros - nesse caso, os parceiros fabricantes de dispositivos - na verdade eles não apoiaram seus parceiros, e ao invés disso a Apple processou a HTC, a Apple processou a Samsung, a Apple processou a Motorola, a Microsoft processou a Motorola e a Google abandonou os fabricantes de dispositivos a sua própria sorte. Eles tiveram que lidar com o problema. Não surpreendentemente, os fabricantes de dispositivos não ficaram muito entusiasmados. Durante o ano passado, a Google começou a perceber que essa estratégia não estava funcionando muito bem. $\mathrm{O}$ resultado dessa estratégia foi que as incertezas criadas para o Android estavam gerando uma dinâmica na qual empresas como a Microsoft eram capazes de negociar acordos com a HTC. Nós fechamos um acordo muito grande com a Samsung na última semana e com outros. Então a Google pensou: "o que nós vamos fazer?" E ela disse: "nós vamos tentar comprar algumas patentes que outras pessoas infringem, para que assim talvez as pessoas não nos processem." Há um conceito que você vê no mundo patentário chamado de destruição mútua assegurada. Se eu tenho patentes de que você necessita, e você tem patentes de que eu necessito, talvez nós dois nos deixemos em paz.

Assim, munida do portfólio da Nortel, a Google estava basicamente enviando a mensagem, me parece que especialmente para a Apple, assim como para várias outras empresas: "nós não vamos fazer negócio com Revista de Direito, Estado e Telecomunicações, v. 4, n. 1, p. 197-236 (2012) 
vocês. Nós não vamos licenciar as patentes que vocês têm que nós infringimos. Ao invés disso, nós vamos adquirir a Nortel e nós vamos tentar utilizar o portfólio da Nortel contra vocês." Não é preciso ser um cientista espacial para entender que isso provavelmente não deixará os demais atores da indústria em uma posição confortável. A Apple, então, disse: “ok, nós vamos apresentar uma proposta para o porfólio da Nortel contra você." A Microsoft reuniu uma coalizão de empresas chamada de "Rock Star" - um consórcio - e esse era um consórcio com a RIM e com cerca de outras sete ou oito empresas na indústria, que apresentaram uma proposta e a Google apresentou a sua também.

Ao final, as propostas chegaram a um valor tão alto que a Apple decidiu que ela deixaria de atuar no leilão sozinha, e iria se juntar ao consórcio "Rock Star" que foi criado pela Microsoft. Ou seja, era um leilão entre o consórcio "Rock Star" e o consórcio que consistia da Google e da Intel. O consórcio "Rock Star" acabou vencendo.

Foi logo após isso que a Google decidiu comprar a Motorola, já que ela não poderia comprar o portfólio da Nortel. O que é anormal a respeito do portfólio da Motorola é que suas patentes já estão no contencioso. A Apple processou a Motorola. A Microsoft também processou a Motorola. Por conseguinte, é muito difícil de ver como isso realmente funcionará da forma como o portfólio da Nortel teria funcionado. Mas é isso que está acontecendo.

Ao final, você pode dizer: "aonde tudo isso acabará?". Eu acho que acabará um dia com um conjunto de acordos de licenciamento. É assim que essas coisas quase sempre acabam. E é por isso que a Microsoft está disposta a dizer: "veja, isso é o que faz mais sentido do ponto de vista prático e portanto aqui está uma abordagem clara. Nós iremos licenciar nossas patentes. Aqui está uma lista de preços. Você pode ver claramente o que elas custam e pode ver que nossa lista de preços foi boa o suficiente para Samsung, ela foi boa o suficiente para a HTC e eu acho que um dia ela será boa o suficiente para todos os demais". Enfim, é uma dinâmica muito interessante, mas também uma época complicada para essas questões patentárias. 
Prof. Márcio Iorio Aranha:

Muito bem. Temos que encerrar por aqui, mas foi um excelente evento. Há um grupo de estudos nesta universidade estudando indicadores jurídicos para estudos comparados de telecomunicações. Essa apresentação de hoje nos inspirou a envidarmos novos esforços no que tange à computação em nuvem, segurança, privacidade e outros assuntos ora mencionados. 